\title{
KARAKTERISTIK LANSEKAP BUDAYA DI DUSUN KAJUARA, KABUPATEN BONE SULAWESI SELATAN
}

\author{
Hamka \\ Program Studi Arsitektur \\ Fakultas Teknik Sipil dan Perencanaan, Institut Teknologi Nasional Malang \\ E-mail: hamka07@lecturer.itn.ac.id
}

\begin{abstract}
Abstrak
Lansekap merupakan kondisi bentang alam dengan karakteristik unsur dan elemen tertentu pada suatu wilayah. Lansekap pada suatu permukiman merupakan hasil interaksi antara manusia dengan alam dan budaya yang menjadi latar belakang ciri identitas suatu lansekap. Khususnya pada lansekap budaya dengan latar belakang sosial masyarakat yang berbeda-beda di tiap daerah di Indonesia. Peranan kondisi geografis dan budaya pada suatu kelompok masyarakat atau suku menarik dikaji kaitannya dalam hal lansekap budaya pada lingkungan permukiman. Kajian ini akan membahas karakteristik lansekap budaya permukiman Dusun Kajuara Kabupaten Bone dengan pendekatan metode kualitatif analsis deskriptif berdasarkan 13 komponen lansekap budaya. Hasil pembahasan menunjukkan bahwa, letak geografis wilayah dan sosial budaya masyarakat di Dusun Kajuara yang sebagian besar sebagai petani berpengaruh terhadap karakter lansekap budaya permukiman yang masih didominasi oleh unsur dan elemen alami pada softscape dan hardscape lingkungan.
\end{abstract}

Kata-kata kunci: komponenen lansekap, lansekap budaya, lansekap tradisional

\section{THE CHARACTERISTICS OF CULTURAL LANDSCAPE IN KAJUARA VILLAGE, BONE REGENCY SOUTH SULAWESI}

\begin{abstract}
Landscape is a condition with its landscape elements characteristic and specific elements of the region. Landscape on a settlement is the result of interaction between human and nature and culture which blends into the background characteristics of the identity of a landscape. Particularly in the cultural landscape with socially different backgrounds of each region in Indonesia. The role of geography and culture of a community or ethnic group is interesting to study in terms of the cultural landscape in the neighborhoods. This review will discuss the characteristics of the cultural landscape settlements of Dusun Kajuara Bone district with qualitative method approach which is based on 13 components of the cultural landscape. The results of the discussion showed that the geographical location and social and cultural area in the Kajuara Village, mostly as farmers, affected the landscape character of the settlement that is still dominated by natural factors and elements on softscape and hardscape settlements.
\end{abstract}

Keywords: cultural landscape, landscape component, traditional landscape 


\section{Pendahuluan}

Masyarakat di Dusun Kajuara ini merupakan etnis Suku Bugis yang sebagian besar berprofesi sebagai petani. Secara umum pola permukiman masyarakat Suku Bugis berdiam bersama di suatu tempat atau desa dimana mata pencaharian mereka berada disekitar tempat itu. Dengan kata lain, pola permukiman suku bugis adalah permukiman yang berdekatan dengan tempat bekerja. Konsep ini menyebabkan adanya kampung pallaonruma (perkampungan petani yang biasanya tidak jauh dari areal persawahan atau perkebunan) dan pakkaja (perkampungan penangkap ikan yang tidak jauh dari pantai atau danau).apabila di dalam kampung terdapat sungai maka rumah-rumah mereka didirikan berderet membelakangi sungai. Kampung ada jaringan jalan, maka rumah-rumah mereka didirikan berderet menghadap ke jalanan tersebut (Hasan, \& Prabowo, 2002).

Lansekap budaya berkaitan erat dengan masyarakat sebagai pelaku didalamnya, yaitu masyarakat adat atau tradisonal. Masyarakat ini masih memegang teguh pola kehidupan tradisional, dimana mereka memiliki kesamaan teritorial, kesamaan keturunan (genealogis), serta kesamaan wilayah dan keturunan (teritorial-genealogis). Selain itu mereka memiliki kearifan lokal dalam mengelola alam lingkungannya, adat istiadat, dan hukum adat. Lansekap budaya erat kaitannya dengan budaya, dimana struktur sejarah didalamnya belum terhapus atau dipengaruhi secara mutlak oleh pemanfaatan lahan secara modern, serta lokasi dimana masih banyak terdapat peninggalan masa lalu dan tetap bertahan sampai saat ini. Lansekap budaya merupakan bagian dari struktur sejarah didalamnya belum terhapus atau dipengaruhi secara mutlak oleh pemanfaatan lahan secara moderen dan tetap bertahan sampai saat ini karena adanya norma dan adat kebiasaan yang diikuti secara turun temurun. Kebudayaan tradisional masyarakat adat merupakan akumulasi dari upaya harmonisasi manusia dan alam, dimana kebudayaan ini dibentuk oleh lingkungan hidup mereka. Lansekap budaya merupakan perpaduan antara dinamika kehidupan manusia dengan bentukan alamnya. Didalamnya terdapat kearifan manusia dalam mengatur sistem sosial dan cara mengorganisasikan ruang pada lingkungannya (Platcher \& Rossler, 1995).

Lansekap budaya merupakan sebuah wilayah geografis, sumber daya alam dan budaya, terkait dengan peristiwa bersejarah, aktifitas, orang, dan pameran mengenai nilai estetika dan budaya, terdapat 4 jenis lansekap budaya, yaitu lansekap situs bersejarah, desain lansekap bersejarah, lansekap vernakular, dan lansekap etnografi, (Page, et al, 1998:12). Karakteristik lansekap termasuk dalam aspek tangible dan intangible dari beberapa periode, aspek individu dan kelompok memberikan sebuah karakter sejarah dan membantu memberikan pemahaman budaya. Karakter lansekap diukur dari jarak pola skala dan hubungan detail dan material tapak, untuk memahami lansekap budaya tersebut, dapat dikaji berdasarkan 13 komponen lansekap budaya, (Page, et al, 1998:53), yaitu: sistem dan ciri alam, organisasi ruang, tata guna lahan, tradisi budaya, penataan cluster, sirkulasi, topografi, vegetasi, bangunan, view dan vista, fitur air buatan, fitur berskala kecil, dan kawasan arkeologis.

Kebudayaan masyarakat tradisional merupakan akumulasi dari upaya harmonisasi manusia dan alam, dimana kebudayaan ini dibentuk oleh lingkungan hidup mereka. Lansekap budaya merupakan perpaduan antara dinamika kehidupan manusia dengan bentukan alamnya. Didalamnya terdapat kearifan manusia dalam mengatur sistem sosial dan cara mengorganisasikan ruang pada lingkungannya (Platcher et al, 1995). Budaya merupakan hasil cipta, karya, dan karsa manusia dalam mempengaruhi kehidupannya. Adanya sistem nilai sebagai inti dari suatu sistem kebudayaan, menjiwai semua pedoman yang mengatur tingkah laku warga pendukung kebudayaan yang bersangkutan. Pedoman tingkah laku itu adalah adat istiadat, sistem norma, aturan etika, aturan moral, aturan sopan santun, pandangan hidup, idiologi pribadi (Kluckhohn dalam Koentjaraningrat, 1986). Pola lain yang terbentuk adalah sejumlah masyarakat berdiam bersama dalam suatu tempat, sebagian yang lain menyebar di luar tempat tersebut. Disini tradisi sangat dipegang kuat oleh masyarakat. Begitupula dengan sikap gotongroyong masyarakatnya, walaupun hubungan dengan sesama individu dalam proses usaha perekonomian telah bersifat komersial (Nurjannah, 2003). Pada 
umumnya tempat kediaman mereka berbentuk persegi dengan pola jaringan jalan secara keseluruhan berbentuk empat persegi panjang.

Permukiman mempunyai kecenderungan untuk mengelompok dekat jalan utama dan lokasi mata pencaharian dan tidak tersusun di sekitar pusat tertentu baik yang bersifat politis (mengitari rumah penguasa, kepala desa),religius (tempat-tempat ibadah tersebar secara acak), maupun ekonomis yang ditandai dengan adanya pasar atau pusat perbelanjaan lainnya. Pola permukiman suku bugis umumnya berorientasi ke arah lautan, karena mata pencaharian mereka umumnya adalah nelayan, namun bila masyarakat tersebut jauh dari pusat atau tanah leluhur mereka, maka bentuk permukimannya akan linear (tidak lagi cluster), namun arah menghadap atau orientasi bangunannya tetap. (Mattulada dalam Suwarno, 2000).

Berdasarkan penjelasan tersebut maka perlu dikaji lagi karakteristik lansekap pada permukiman di Dusun Kajuara ini terkait dengan budaya masyarakat sebagai petani dan kondisi geografis dusun yang berada di wilayah perbukitan dengan kondisi lingkungan yang masih alami, berdasarkan 13 komponen lansekap budaya. Selain itu, perlu dilihat juga karakteristik dari segi budaya atau tradisi masyarakat yang terdapat pada komponen tersebut, apakah terdapat hal-hal terkait budaya, tradisi, adat, atau aturan masyarakat pada masing-masing komponen lansekap yang akan dikaji.

\section{Metodologi Pembahasan}

Pembahasan dilakukan dalam bentuk deskriptif analisis dari data dan referensi sumber, dan hasil observasi lapangan yang didapatkan sebagai bahan pembahasan. Analisis dilakukan untuk mengidentifikasi karakteristik lansekap budaya permukiman di Dusun Kajuara. Karakteristik lansekap akan dibahas berdasarkan 13 komponen menurut (Page et al, 1998) lansekap budaya yaitu sistem dan ciri alam, organisasi keruangan, penggunaan lahan, tradisi budaya, penataan cluster, sirkulasi, topografi, vegetasi, bangunan, view, fitur air, fitur skala kecil, dan kawasan arkelogis. Masing-masing komponen akan dijelaskan secara deskriptif sesuai dengan hasil observasi di lapangan dan kemudian mengkajinya, apakah terdapat nilai budaya pada masing-masing komponen tersebut, selanjutnya dilakukan kajian keterkaitan hasil pembahasan dengan kajian pustaka yang telah dipaparkan pada bagian pendahuluan

Sub Judul bagian 2

\section{Pembahasan}

Wilayah studi terletak Dusun Kajuara, Desa Mulamenre'e, Kecamatan Ulaweng, Kabupaten Bone, Sulawesi-Selatan, secara administratif terdiri dari 27 kecamatan, 333 desa dan 39 kelurahan. Kabupaten ini terletak $174 \mathrm{~km}$ ke arah timur Kota Makassar, berada pada posisi $4^{\circ} 13^{\prime}-5^{\circ} 6^{\prime} \mathrm{LS}$ dan

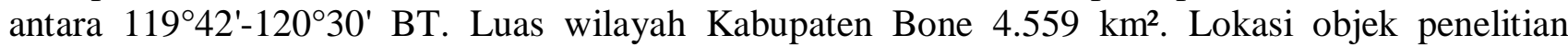
berada di Dusun Kajuara, Desa Mulamenre'e, Kec. Ulaweng, Kab. Bone, Sulawesi Selatan dan terletak $11 \mathrm{Km}$ dari ibukota kecamatan dan sekitar $40 \mathrm{Km}$ dari kota Bone. Desa ini merupakan desa terpencil yang dulunya dipimpin oleh orang yang bergelar Arung/Sulewatang Kajuara. Desa Mulamenre'e terdiri dari tiga dusun yaitu Dusun 1 Kajuara, Dusun 2 Ajulotong, dan Dusun 3 Bukku. Secara administrasi Dusun Kajuara merupakan pusat desa atau ibukota desa Mulamenre'e. Dusun Kajuara ini terdiri dari 5 RT yaitu RT 1 meliputi Paccanring dan La'gangka, RT 2 Kampiri, RT 3 Cilellang, RT 4 Mappenrae, RT 5 meliputi Kajuara, Laleng Bata, dan Latolang. 


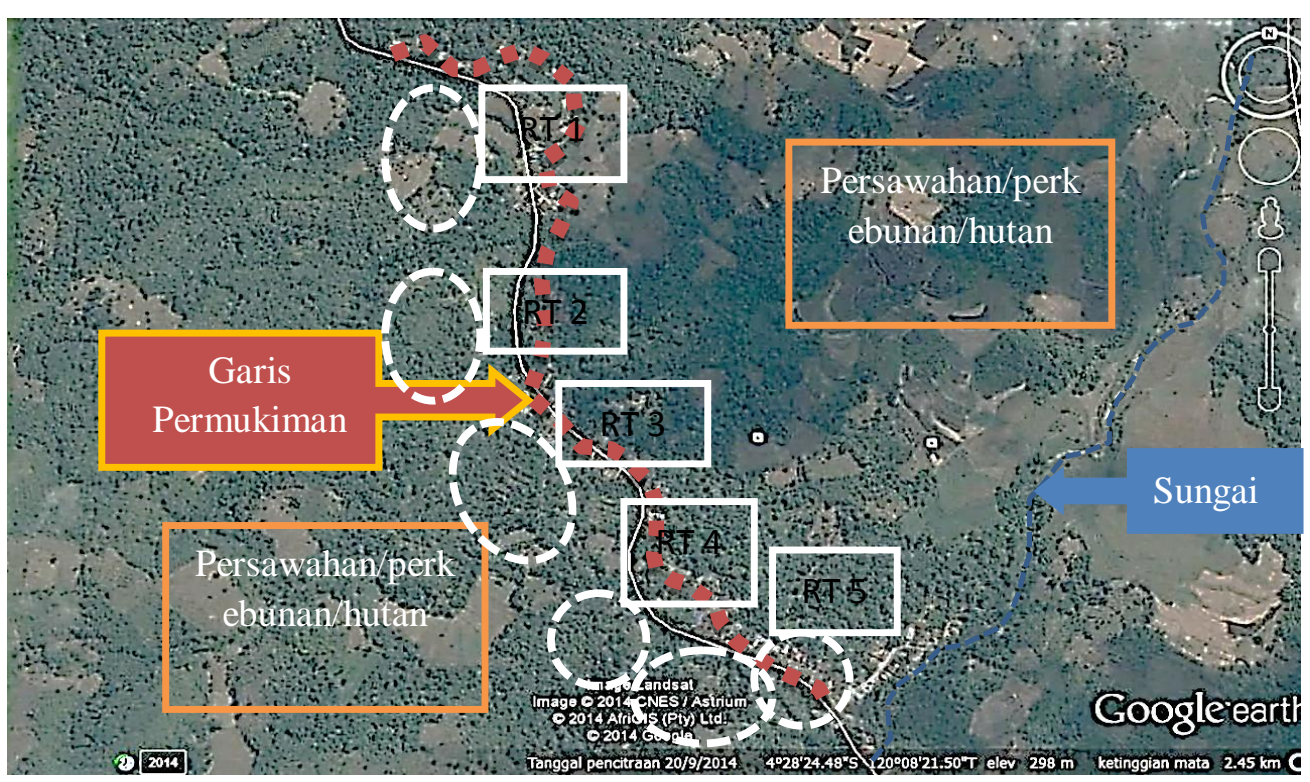

Gambar 1. Lokasi Wilayah Dusun Kajuara

Sumber: Observasi lapangan, 2015

Berikut ini pembahasan karakteristik lansekap budaya di Dusun Kajuara berdasarkan 13 komponen lansekap budaya:

\section{Sistem dan Ciri Alam}

Dusun ini merupakan tipe perkampungan petani, bentuk permukaan alam sebagian besar wilayahnya merupakan perkebunan, sawah, dan juga hutan-hutan alami miliki masyarakat setempat. Posisi persawahaan, kebun, dan hutan berada di sebelah timur dan barat permukiman yang melintas dari selatan ke utara. Dari sisi geomorfologi kawasan ini secara umum tidak ada perubahan dari bentuk permukaan alam, kecuali pada lingkungan permukiman yang semakin berkembang pembangunannya khususnya pada rumah-rumah masyarakat setempat.

Hidrologi kawasan bersumber pada sungai yang melintas dari barat ke arah timur tepat di batas Dusun Kajuara sebelah selatan. Untuk masyarakat yang berada di dekat sungai, akan melakukan kegiatan cuci dan mandi disungai. Masyarakat yang jauh dari sungai memanfaatkan sumur-sumur yang sudah ada sejak nenek moyang mereka. Akibat perkembangan teknologi akhirnya masyarakat memanfaatkan pompa air untuk mendistribusikan air dari sumur ke masing-masing rumah, yang dulunya diambil secara manual atau alat sederhana, sehingga sekarang ini sudah jarang melakukan kegiatan cuci mandi secara langsung di tiap-tiap sumur. Begitupun air dari sungai, untuk kondisi sekarang ini sudah di distribusikan ke tiap-tiap RT melalui saluran pipa ke beberapa bak penampungan. Masyarakat juga memanfaatkan air hujan untuk bersih-bersih yang ditampung dari atap rumah ke bak penampungan.

Kondisi cuaca di dusun ini akan mengalami suhu yang panas pada siang hari dan hawa yang dingin di malam hari, dan pada saat musim hujan menghasilkan curah hujan yang sangat tinggi. Wilayah ini merupakan permukiman di daerah pegunungan dengan kondisi ekologi alam lingkungan yang masih mendominasi. Respon terhadap alam pada tapak ditunjukkan dengan memberikan jarak yang luas antara rumah yang satu dengan yang lainnya dan membuat halaman depan rumah yang luas. Dari segi rumahnya sebagian besar masih berupa rumah panggung tradisional. Ciri lingkungan alam permukiman dusun berada di antara kebun-kebun (Gambar 2). 


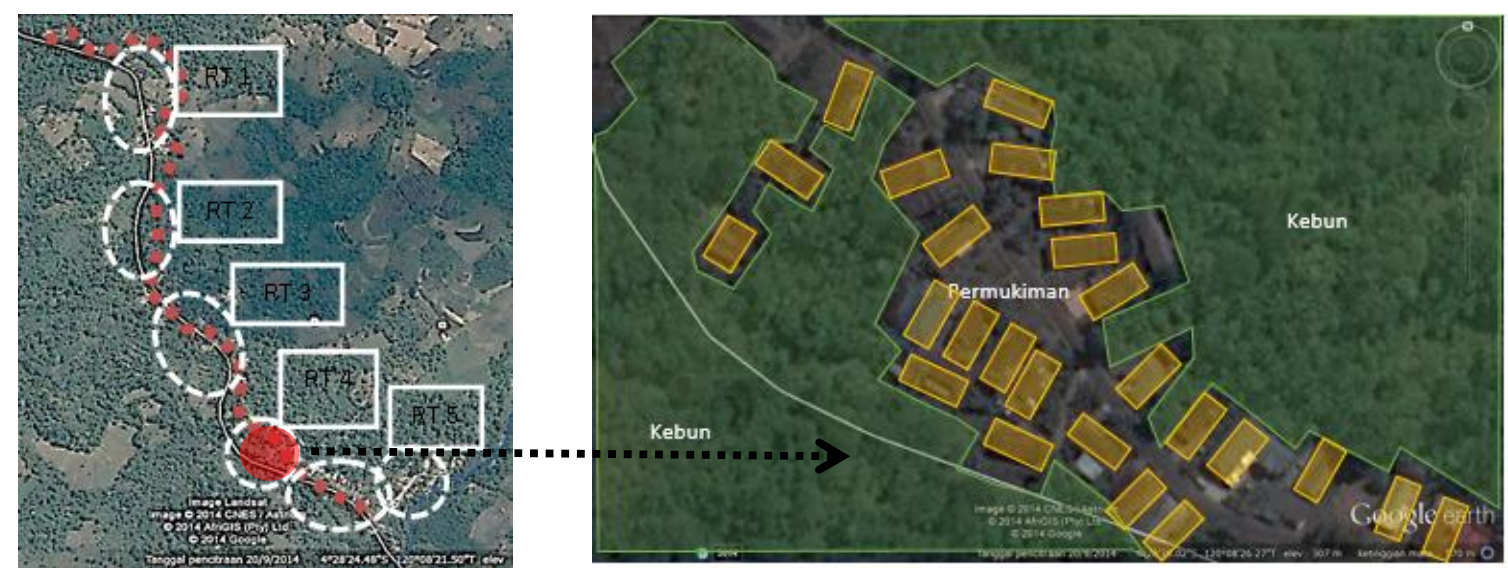

Gambar 2. Ciri lingkungan permukiman

Sumber: Hasil analisis, 2016

\section{Organisasi Keruangan}

Organisasi keruangan menunjukkan hubungan antara elemen solid, void, dan sirkulasi menghasilkan beberapa bentuk organisasi keruangan di beberapa RT, meskipun dari segi sirkulasi secara umum membentuk pola linier sehingga elemen solid berupa bangunan rata-rata berorientasi ke sirkulasi jalan desa. Namun terdapat beberapa perbedaan pola organisasi ruang yang ditunjukkan pada beberapa RT yang ada di dusun ini. Yaitu pola organisasi linier berjejer yang unit bangunannya mengikuti sirkulasi dan jaraknya berdekatan dengan jalan, yang kondisi topografinya berupa dataran (Gambar 3. A), pola organisasi bangunan linier mengikuti jalan dan jaraknya berjauhan dengan sirkulasi jalan serta orientasi hadap bangunannya rata-rata tidak menghadap ke jalan dengan topografi di perbukitan(Gambar 3.B), dan pola organisasi ruang permukiman yang mengelompok padat dan meyebar (Gambar 3.C).

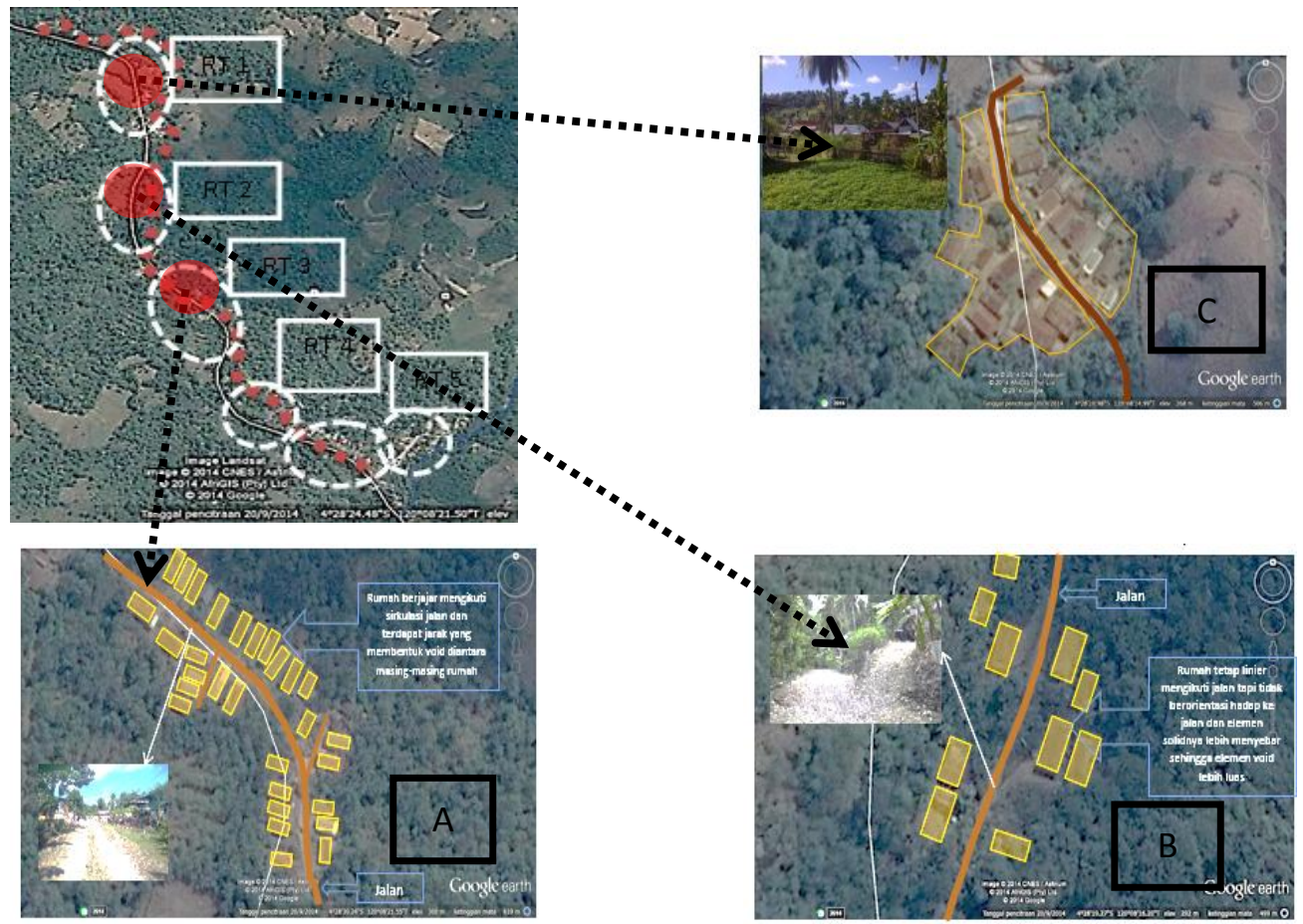

Gambar 3. Tipe Organisasi Keruangan

Sumber: Hasil analisis, 2016 
Pola organisasi keruangan berorientasi terhadap jalan dengan membentuk pola secara linier, dengan tipe jarak antara bangunan yang padat dan yang jarang tergantung pada kondisi topografi serta arah orientasi hadap rumah yang dijadikan patokan. Sebagian besar rumah yang berada di pinggir jalan, posisi orientasinya akan cenderung ke jalan, kecuali untuk beberapa rumah yang posisinya memanjang sejajar dengan jalan itu sendiri.

\section{Penggunaan Lahan}

Secara makro kawasan merupakan lahan perkebunan, persawahan, ataupun hutan alami yang ada diperbukitan ataupun di lingkungan permukiman masyarakat di dusun ini. Sebagian besar lahan digunakan untuk perkebunan coklat, persawahan yang ditanami tanaman musiman seperti padi, jagung dan ubi-ubian. Pada area lingkungan perumahan dan di sekitaran rumah juga dimanfaatkan untuk berkebun, selain rumah masyarakat berada diantara kebun-kebun pohon coklat. Pada halaman rumah atau pekarangan rumah biasanya digunankan untuk menanam tanaman bumbu dapur seperti tomat, cabe, lengkuas, sre dan yang lainnya. Tiap-tiap rumah memiliki ruang halaman yang luas yang biasanya digunakan untuk menjemur hasil panen seperti coklat, padi, dan jagung. Sirkulasi bahu jalan desa pun sering dimanfaatkan untuk menjemur hasil panen tersebut.

Halaman rumah tersebut juga digunakan untuk bermain ataupun untuk sekedar berkumpul khususnya di sore hari. Ruang-ruang luar terbuka tersebut dibuat multifungsi untuk mewadahi beberapa kegiatan sekaligus, seperti untuk kegiatan hajatan pernikahan, bermain dan berolahraga. Masyarakat juga menggunaan lahan pada kolong rumah untuk beraktifitas, bekerja, dan menyimpan barang. Pemanfaatan lahan tidak ada yang berfungsi permanen untuk satu kegiatan saja, pada lahan ladang dan persawahan ditanami tanaman musiman secara bergantian, lahan-lahan pada lingkungan permukiman juga dimanfaatkan untuk beberapa fungsi sekaligus (Gambar 4).
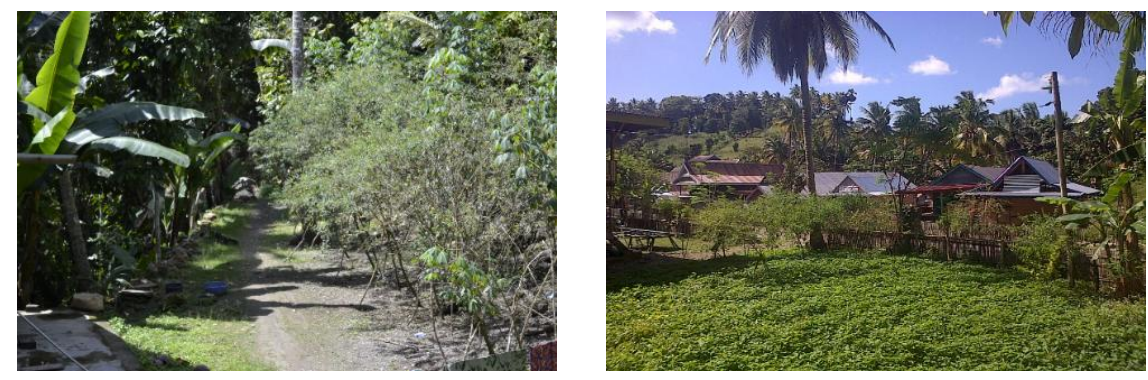

Gambar 4. Pemanfaatan Halaman Rumah untuk Bercocok Tanam Sumber: Dokumentasi, 2015

\section{Tradisi Budaya}

Tradisi budaya masyarakat di dusun ini tidak banyak menggunakan lahan lansekap sebagai wadah atau tempat pelaksanaan tradisi. Tradisi sebagian besar dilakukan di rumah masing-masing yang melaksanakan. Acara-acara tradisi yang dilakukan diruang terbuka terkait dengan acara pernikahan yang rata-rata dilakukan di halaman rumah masing-masing karena tiap rumah memiliki halaman atau pekarangan yang cukup luas sehingga tidak perlu menggunakan badan jalan sebagai tempat acara. Tradisi lainnya adalah maccuda-cudangeng yaitu acara bersih bersih sumur dilakukan tiap sekali dalam setahun di masing-masing sumur yang ada di lingkungan masyarakat, yang dianggap sebagai sumber air kehidupan bagi masyarakat. Tradisi lainnya adalah mattuana yaitu tradisi persembahan terhadap luluhur, dan benda-benda peninggalan seperti benda pusaka dan kitab lontara. Tradisi ini dilakukan di laleng bata sebagai tempat bersejarah dan pusat kampung, karena di tempat inilah benda-benda pusaka peninggalan nenek moyang disimpan. 


\section{Penataan Cluster}

Pola penataan cluster permukiman berbentuk linier mengikuti jalan desa secara alami. Permukiman di Dusun Kajuara dibagi menjadi 5 RT yang dikelompokkan dalam cluster-cluster permukiman. Setiap cluster permukiman memiliki batas atau dipisahkan oleh batas alami (masyarakat menyebutnya dengan sebutan pallawangeng) dengan cluster RT yang lainnya (Gambar $5)$.

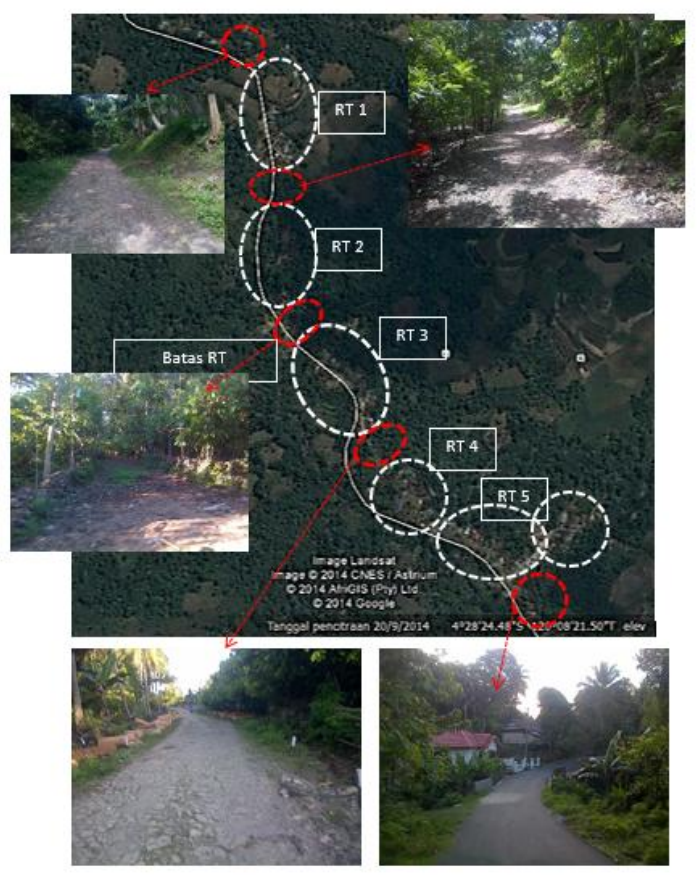

Gambar 5. Pola Cluster Permukiman Sumber: Hasil analisis, 2016

\section{Sirkulasi}

Pola sirkulasi dusun merupakan pola sirkulasi linier, di dusun ini hanya memiliki satu jalan desa berbentuk linier melintasi tiap-tiap RT yang ada di dusun ini. Sirkulasi lainnya berupa jalan setapak yang menghubungkan antara rukun tetangga dan juga jalan setapak yang menjadi akses bagi masyarakat menuju ke kebun ata sawahnya masing-masing. Unsur jalan desa sekarang ini dibagi menjadi 2 jenis berdasarkan materialnya, yaitu jalan aspal yang melintas dari RT 5 hingga ke perbatasan RT 4 dengan RT 3. Dari Perbatasan RT 4 dan RT 3 hingga ke RT 1 permukaan jalannya masih berupa unsur bebatuan dan terdapat satu titik di RT 2 yang jalannya di cor semen. Untuk jalanjalan setapak untuk menuju ke rumah tetangga ataupun ke persawahan/kebun berupa unsur tanah dan bebatuan. 

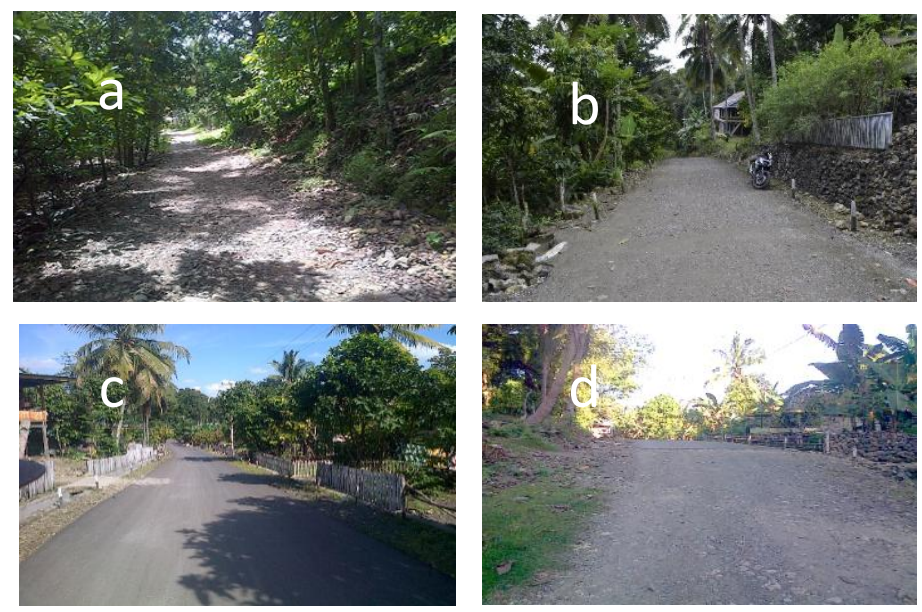

Gambar 6. a: jalan bebatuan, b: jalan di cor, c: jalan aspal, d: perbatasan jalan aspal dan bebatuan Sumber: Dokumentasi, 2015

\section{Topografi}

Dusun Kajuara merupakan desa yang berada pada kondisi topografi perbukitan dengan kondisi bentang alam yang masih didominasi oleh unsur alami. Permukiman RT 5, RT4, dan RT 3 berada pada kondisi topografi tanah yang relatif datar, sedangkan permukiman RT 2 dan RT 1 berada di wilayah perbukitan dan lembah. Kondisi tersebut berpengaruh terhadap pola permukiman yang berada di masing-masing RT. Permukiman yang berada di wilayah topografi tanah yang datar cenderung membentuk pola yang linier, rumah berjejer mengikuti dan berorientasi ke jalan. Untuk permukiman di wilayah RT yang berada pada kondisi topografi perbukitan dan lembah cenderung menyebar.

\section{Vegetasi}

Vegetasi yang ada di Dusun Kajuara ini terdiri dari vegetasi jenis tanaman hiasan, seperti (kembang kertas, asoka, dan anggrek), tanaman buah-buahan untuk dikomsumsi termasuk tanaman umbi-umbian. Tanaman hiasan dan tanaman buah-buahan tersebut tidak memiliki ketentuan khusus mengenai jenis tanaman yang diperbolehkan atau tidak di Dusun Kajuara ini. Tanaman hiasan ataupun buah-buahan ditanam sesuai dengan keinginan pemilik rumah di lingkungan rumahnya masing-masing, dan pemanfaatan hasil dari tanaman tersebut dapat dinikmati oleh pemilik dan juga tetangga dengan saling meminta ataupun memberi. Jenis tanaman buah-buahan yang ada, seperti pepaya, kelapa, mangga, langsat, nangka, pisang, nanas, dan jambu. Untuk jenis umbi-umbian adalah ubi kayu, ubi jalar, dan talas. Tanaman jenis pepohonan lainnya, seperti pohan lontar pohon pinang, pohon daun kelor, dan pohon coklat. Tanaman-tanaman ini tumbuh secara alami dalam satu lahan secara bersamaan, sehingga dalam satu lahan memiliki banyak jenis vegetasi di dalamnya. 

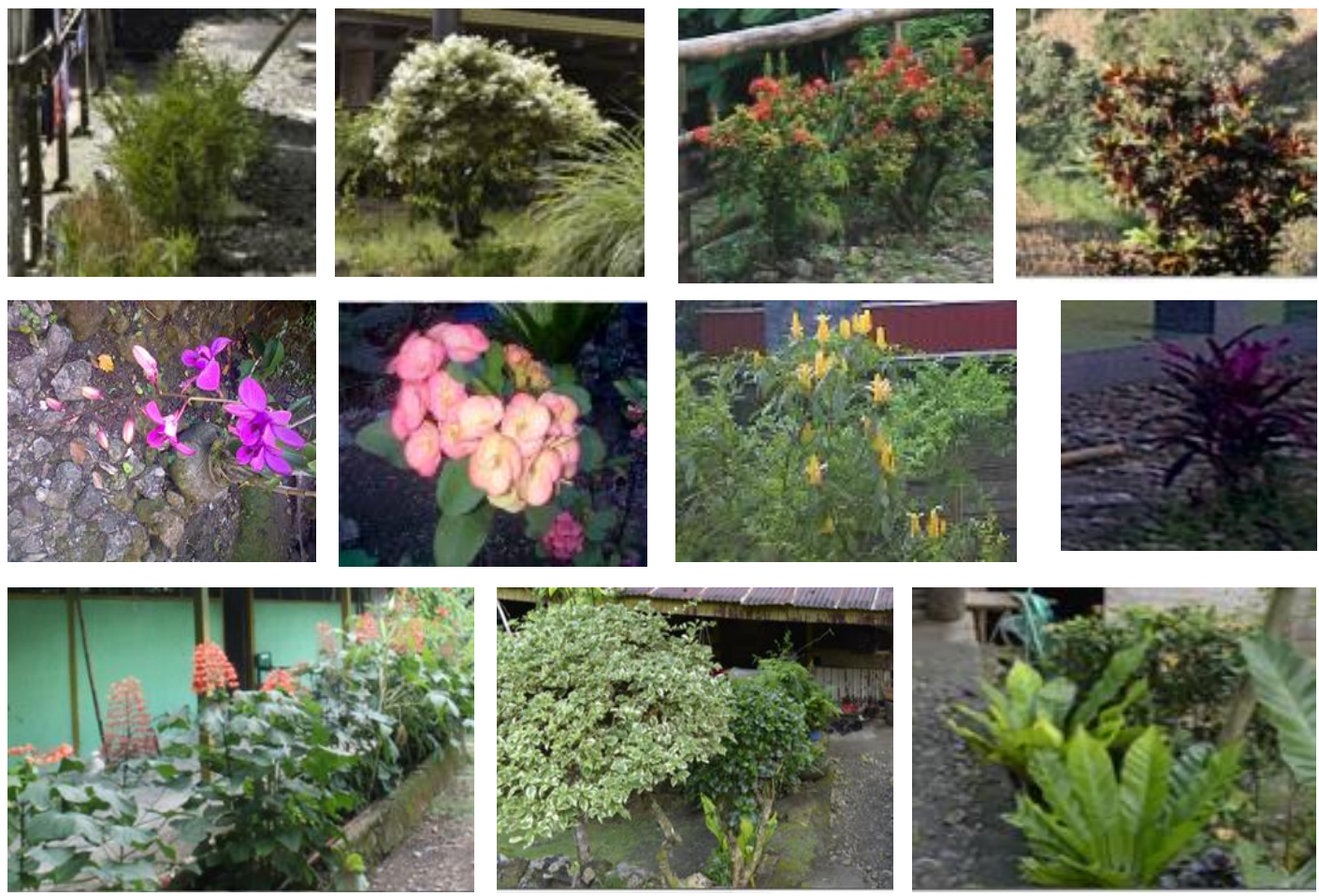

Gambar 7. Ragam Tanaman Hias

Sumber: Dokumentasi, 2015
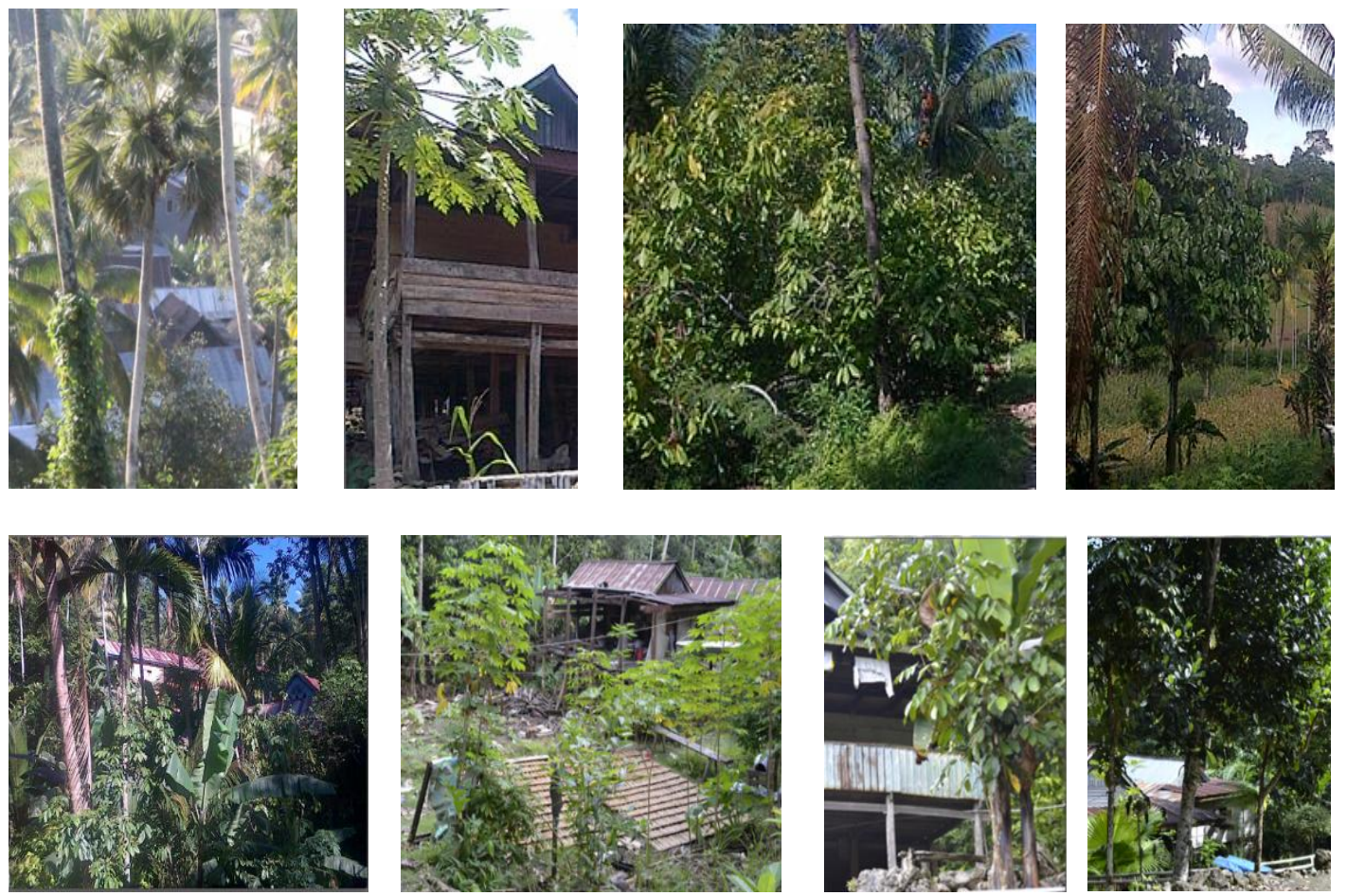

Gambar 8. Ragam Tanaman Konsumsi Sumber: Dokumentasi, 2015 
Berikut ini ragam persebaran vegetasi pada lingkungan hunian salah satu rumah warga yang ada di RT 2 Kampiri, sebagai berikut:
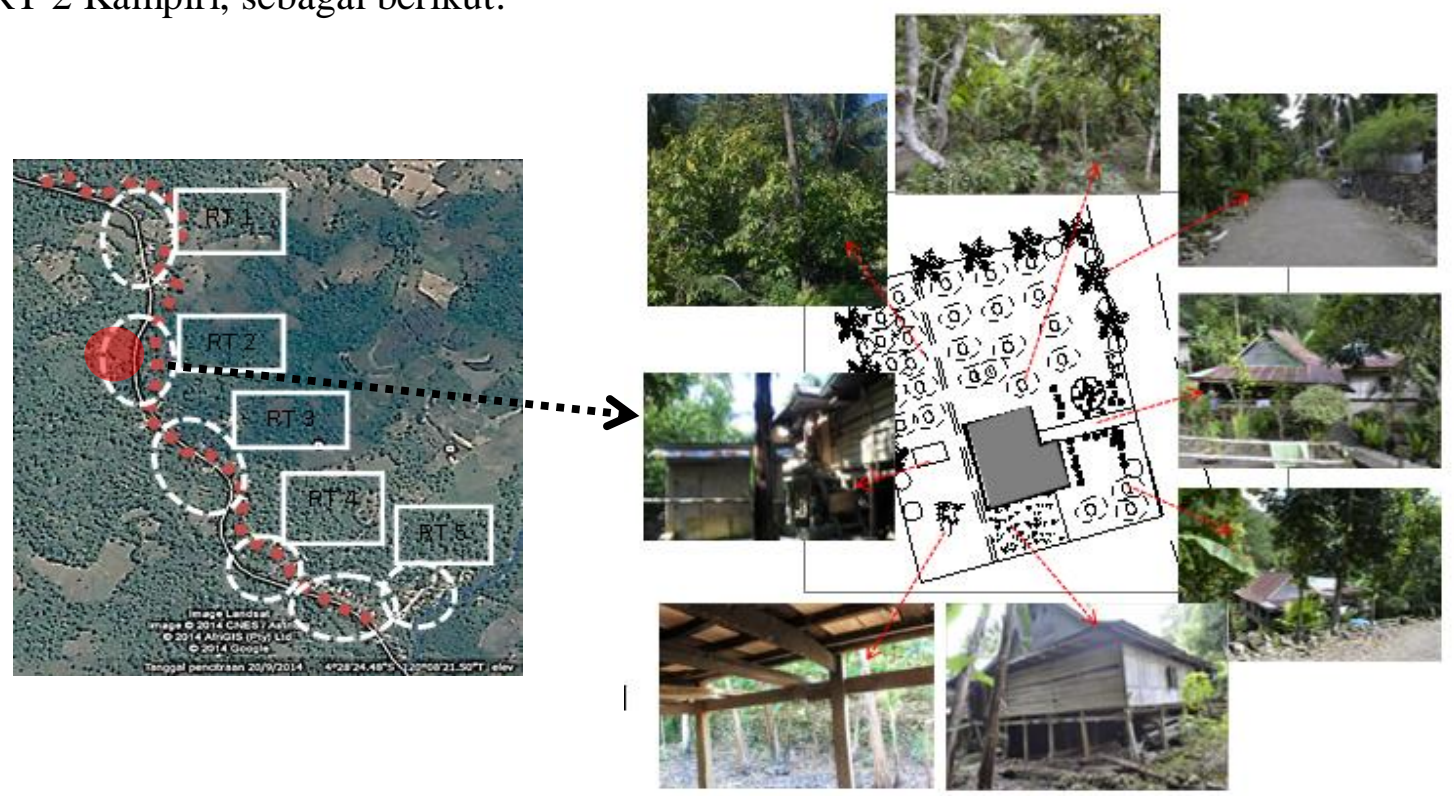

Gambar 9. Ragam Vegetasi pada Lingkungan Ruang Luar Rumah Warga Sumber: Hasil analisis, 2016

\section{Bangunan}

Bentuk bangunan yang ada di dusun ini masih di dominasi oleh bangunan rumah tradisional. Populasi rumah masyarakat di Dusun Kajuara mencapai \pm 180 unit rumah. Bangunan rumah-rumah tradisional lebih banyak ditemukan di wilayah bagian barat dusun (RT 1, 2, dan 3), sedangkan bagian timur dusun (RT 4 dan 5) beberapa diantaranya sudah dalam bentuk bangunan modern. Bagian timur dusun merupakan pusat desa dengan berbagai macam fasilitas desa, seperti sekolah, masjid, kantor desa, dan poskesdes. Pola struktur jalan desa berbentuk linier melintasi permukiman dusun dan kondisi jalan seperti yang telah dijelaskan sebelumnya, insfrastruktur lainnya berupa jembatan yang berada di batas timur dusun yang melintasi sungai Kajuara yang merupakan pintu gerbang masuk ke wilayah Dusun Kajuara.

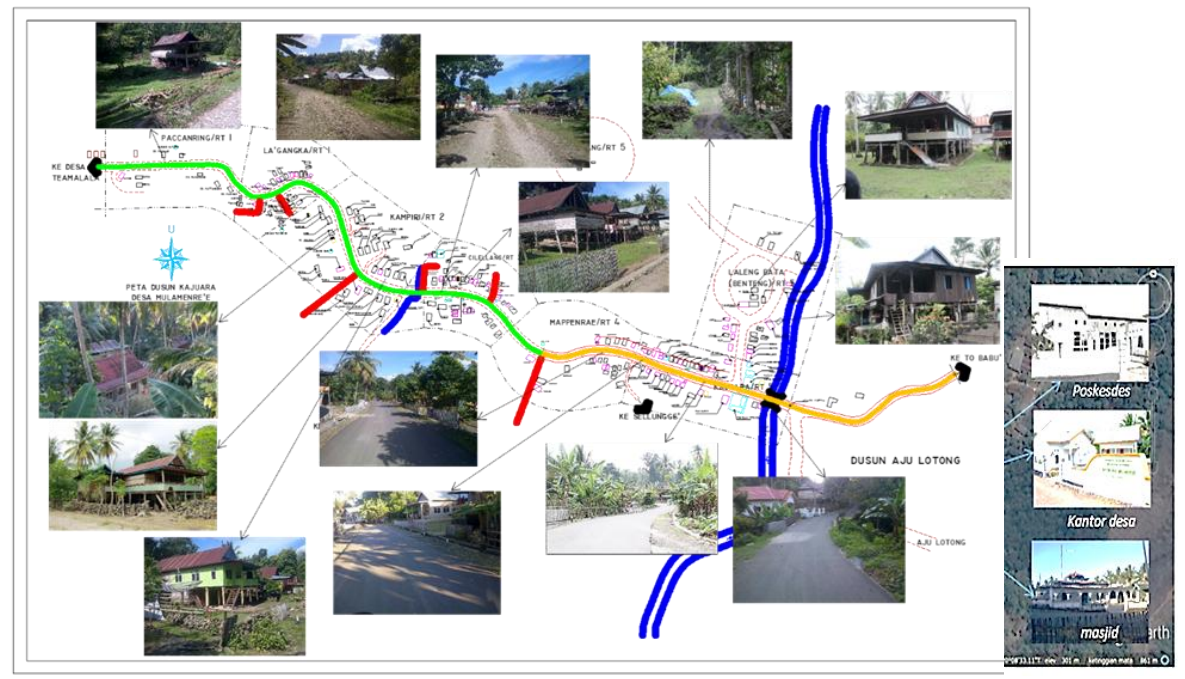

Gambar 10. Persebaran Bangunan dan Infrastruktur

Sumber: Observasi lapangan, 2015 


\section{View}

View dan vista kawasan permukiman sesuai dengan kondisi lingkungan permukiman yang masih alami, sehingga pemandangan yang ada juga masih sangat alami. Dalam permukiman terdapat beberapa view yang dapat dilihat dari perbukitan, view ke perkebunan atau persawahan, dan juga view ke permukiman itu sendiri, (Gambar 11).
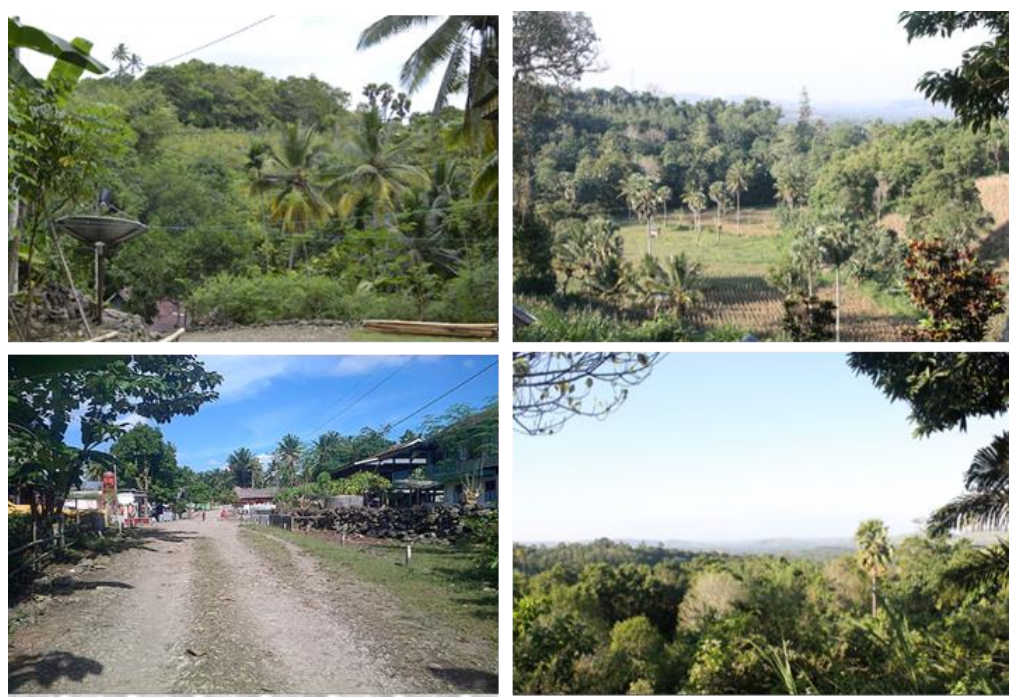

Gambar 11. View pada Lingkungan Permukiman

Sumber: Dokumentasi, 2015

\section{Fitur Air Buatan/Alami}

Fitur air didominasi oleh unsur alami air dari sumur dan sungai, dan tidak terdapat gitur air buatan. Sungai dan sumur ini merupakan sumber air utama masyarakat setempat yang digunaka untuk kebutuhan hidup sehari-hari. Sungai berada di sisi timur dusun sekaligus sebagai batas dusun dan sungai terdapat di tiap-tiap RT yang ada di Dusun Kajuara (Gambar 12).
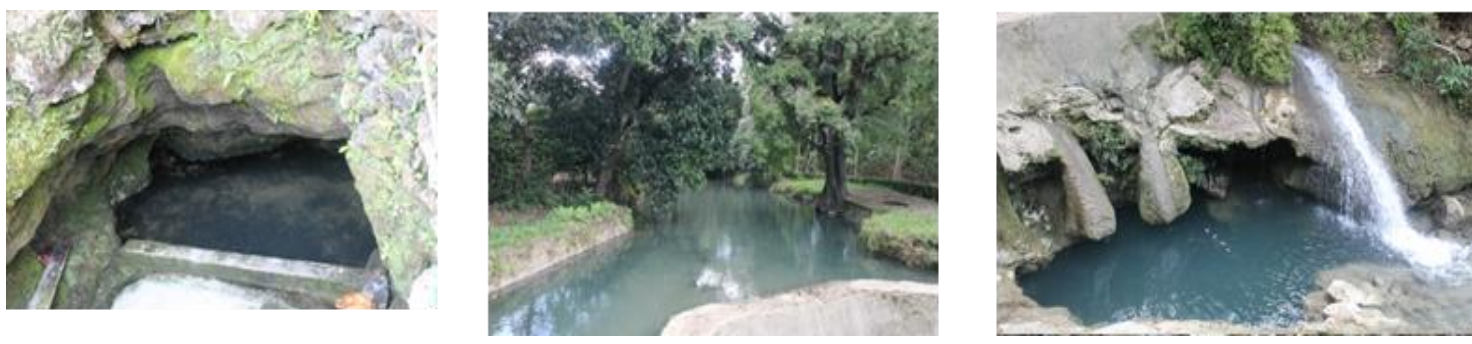

Gambar 12. Fitur Air Alami

Sumber: Dokumentasi, 2015

\section{Fitur berskala Kecil}

Fitur berskala kecil yang banyak di temukan di dusun ini berupa pagar pembatas lingkungan rumah ataupun batas kebun atau persawahan masyarakat yang dibuat dari susunan batu ataupun dari bambu. Fitur-fitur kecil sebagai penanda arsitektural ataupun sebagai simbol lingkungan tidak ditemukan. Pagar yang terbuat dari bambu umumnya digunakan sebagai pagar di depan rumah, sedangkan pagar dari susunan batu umumnya digunakan sebagai pembatas pada samping dan belakang rumah (Gambar 13). 

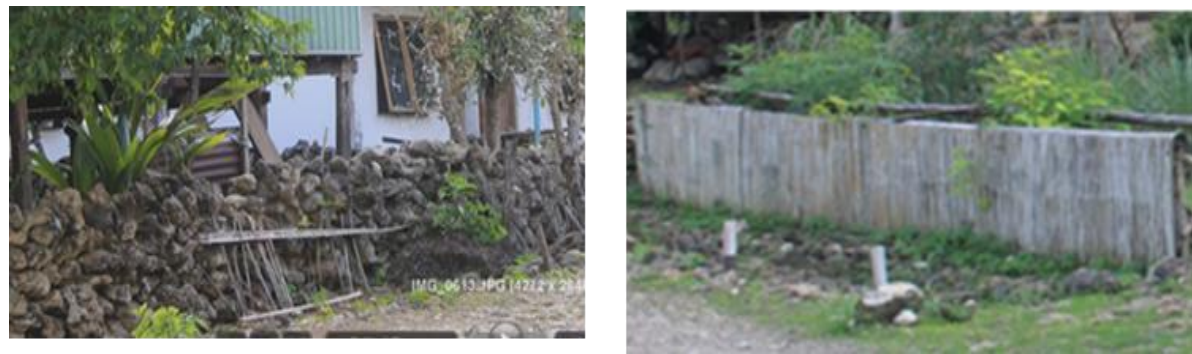

Gambar 13. Pagar dari Susunan Batu dan Bambu Sumber: Dokumentasi, 2015

\section{Kawasan Arkeologis}

Kawasan arkeologis yang ada di dusun ini merupakan tempat bersejarah, di tandai dengan adanya situs tana bangkalae yang didalamnya terdapat gabungan tanah dari 3 kerajaan yaitu kerajaan Bone, Gowa, Wajo sebagai simbol perdamaian, dan di tempat ini merupakan pusat tradisi yang masyarakat menyebutnya dengan mattuana, merupakan tradisi memuliakan garis keturunan dan perawatan benda pusaka serta kitab lontara yang ada di arajangge (museum) di RT laleng bata. Lokasi kawasan ini dikelilingi oleh benteng yang terbuat dari susunan batu mengelilingi situs tana bangkalae. Di dalam kawasan situs ini juga terdapat beberapa hunian masyarakat setempat termasuk dengan museum tempat penyimpanan benda pusaka, (Gambar 14).

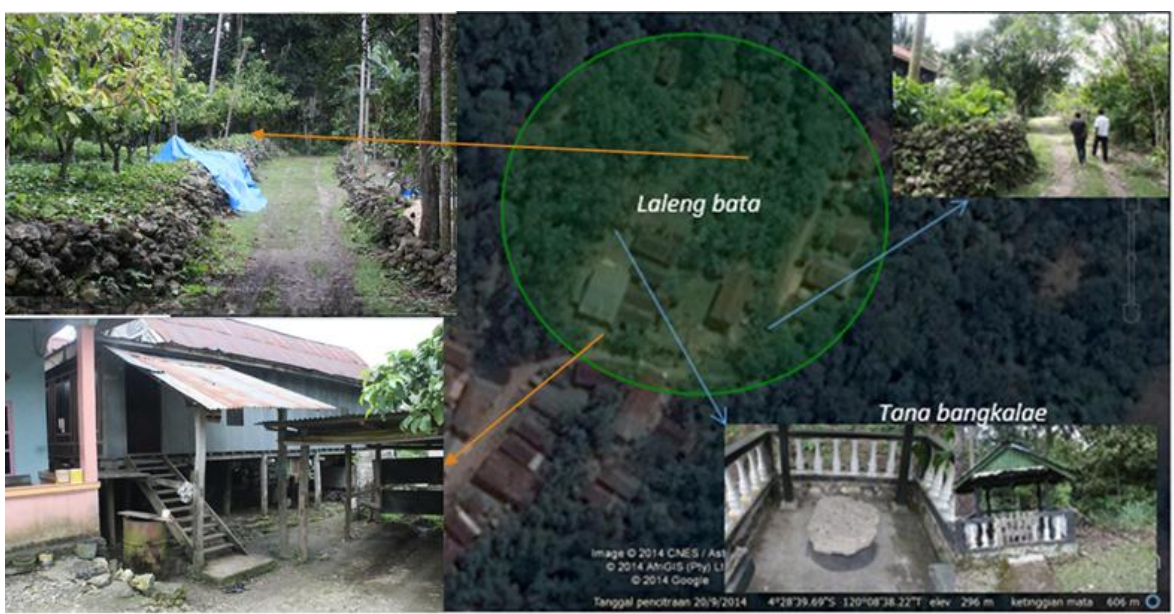

Gambar 14. Kondisi Lingkungan Kawasan Arkeologis Sumber: Observasi lapangan, 2015

Berdasarkan pada hasil pembahasan 13 komponen lansekap budaya diatas menunjukkan bahwa keterkaitan budaya pada masing-masing komponen lansekap tidak ditemukan sebuah aturan-aturan tertentu yang menjadi pakem tatanan lansekap. Karakter pola tatanan lansekap di Dusun Kajuara ini muncul dan berkembang secara alami. Hal-hal yang terkait dengan kepercayaan sifatnya tidak mengikat, tidak ada aturan khusus dalam lingkup makro kawasan. Unsur budaya yang terdapat pada komponen lansekap merupakan hasil dari kehidupan sosial masyarakat Dusun Kajuara yang bekerja sebagai petani, yang pada awalnya masyarakat bermukim secara menyebar agar dekat dengan kebun dan sawah mereka. Namun, semakin berkembangnya populasi penduduk dusun mengakibatkan pola organisasi keruangan lansekapnya berubah menjadi cluster-cluster permukiman yang sekarang ini terdiri dari 5 RT. Masyarakat yang bekerja sebagai petani juga berpengaruh terhadap jenis-jenis vegetasi yang tumbuh di dusun ini. Selain lingkungan alam yang sebagian besar berupa hutan, juga 
ditanami tumbuhan produktif seperti coklat, kelapa, dan pisang. Karakteristik lansekap budaya berdasarkan 13 komponen tersebut secara umum masih didominasi oleh unsur dan elemen alami.

\section{Kesimpulan}

Karakter fisik lingkungan lansekap tradisional permukiman Dusun Kajuara masih didominasi oleh unsur dan elemen lingkungan alami khususnya unsur-unsur softscape vegetasi dan hardscape bebatuan. Unsur vegetasi tersebut sangat beragam berperan penting sebagai sumber penghasilan masyarakat setempat sebagai penghasil bahan makanan pokok dan juga jenis buah-buahan yang ditanam di sawah ataupun kebun. Secara umum tidak ada pola-pola khusus dalam menanam vegetasi, vegetasi ditanam dan tumbuh secara alami dengan fungsinya masing-masing.

Pola permukiman berbentuk cluster yang terhubung secara linier mengikuti jaringan jalan desa yang melintasi Dusun Kajuara. Kondisi permukaan jalan yang melintasi dusun sebagian berupa jalan aspal dan sebagian lagi masih dari unsur bebatuan. Ciri lingkungan permukiman berada di antara kebun-kebun masyarakat, begitupun dengan rumah-rumah masyarakat berada diantara tanamantanaman yang tumbuh disekitar rumah mereka. Jenis rumah masih didominasi oleh tipe rumah tradisional yang terbuat dari kayu, dab beberapa diantaranya berupa rumah modern khususnya untuk gedung-gedung fasilitas desa.

Lansekap yang didominsai oleh unsur-unsur alami menghasilkan view kawasan yang alami yang terlihat dari elemen-elemen lingkungan. Fitur-fitur lingkungan buatan hampir tidak ditemui di dusun ini, fitur air dan fitur berskala kecil lainnya sebagian besar masih bersifat alami. Masyarakat menandai lingkungan mereka dengan elemen-elemen lingkungan alami ataupun elemen bangunan yang ada disekitar mereka. Dusun ini merupakan kawasan permukiman petani yang ada di wilayah perbukitan dengan kondisi lingkungan yang alami. Di dalam dusun terdapat kawasan arkeologis yang merupaka pusat desa yang dijadikan tempat melaksanakan tradisi khusus oleh masyarakat setempat. Lansekap budaya di Dusun Kajuara tumbuh berdasarkan tradisi masyarakat sebagai petani, sehingga lingkungan permukiman mereka didominasi oleh tanaman-tanaman pokok berupa buah-buahan dan juga tanaman musiman yang ditanam di sawah atau kebun serta lingkungan sekitar rumah masyarakat yang ada di Dusun kajuara ini.

\section{Daftar Pustaka}

Hasan, \& Prabowo. (2002). Perubahan Bentuk dan Fungsi Arsitektur Tradisional Bugis di Kawasan Pesisir Kamal Muara, Jakarta Utara. International Symposium 'Building Research and the Sustainability of the Built Environment in the Tropics' Universitas Tarumanegara.

Koentjaraningrat. (1999). Manusia dan Kebudayaan di Indonesia. Djambatan: Jakarta.

Nurjannah \& Anisa. (2003). Pola Permukiman Bugis di Kendari. NALARs Volume 9 Nomor 2 Juli 2010

Page, Robert. R, Cathy Gilbert, Susan A.Dolan. (1998). Guide of Culture Landscape Report. Hal: 53

Plachter, H. dan Rossler, M. (1995). Cultural Landscape: Reconnecting Culture and Nature. Dalam van Droste, B., Placher, H., dan Rossler, M. (Editors). Cultural Landscape of Universal Value.

Suwarno, Nindyo. (2000). Tipologi Spasial Permukiman Transmigran Spontan di Desa Tolai Kecamatan Sausu Kabupaten Donggala. Media Teknik UGM 